\title{
ANALISIS SPASIAL DAN TEMPORAL KOMUNITAS FITOPLANKTON SEKITAR BUDIDAYA LAUT TERINTEGRASI DI TELUK EKAS, NUSA TENGGARA BARAT
}

\author{
I Nyoman Radiarta\#, Erlania, dan Ketut Sugama \\ Pusat Penelitian dan Pengembangan Perikanan Budidaya
}

(Naskah diterima: 5 Februari 2015; Revisi final: 30 Maret 2015, Disetujui publikasi: 5 Juni 2015)

\begin{abstract}
ABSTRAK
Fitoplankton merupakan trofik level paling rendah yang dapat digunakan sebagai indikasi kesuburan perairan. Penelitian ini bertujuan untuk melakukan analisis spasial dan temporal komunitas fitoplankton sekitar budidaya terintegrasi (IMTA) di Teluk Ekas, Nusa Tenggara Barat. Pengamatan lapangan dilakukan selama enam bulan mulai Juni-November 2014. Sebanyak sembilan stasiun pengamatan yang dirancang melingkar dengan jarak 60 m dan 150 m dari titik pusat IMTA (KJA ikan). Data yang dikumpulkan kemudian dianalisis secara deskriptif, indeks ekologi, dan statistik multivariat. Hasil identifikasi jenis dan kelimpahan fitoplankton menunjukkan bahwa jenis Nitzschia sp., Girosygma sp., dan Coscinodiscus sp.; dari kelas Bacillariophyceae merupakan jenis yang dominan ditemukan. Analisis indeks ekologi memberikan gambaran bahwa fitoplankton di kawasan budidaya terintegrasi memiliki indeks keanekaragaman yang rendah, indeks dominansi tergolong kategori rendah-sedang, dan indeks keseragaman yang tinggi. Kelimpahan fitoplankton secara spasial dan temporal menunjukkan bahwa kelimpahan yang tinggi ditemukan pada bulan Agustus-Oktober, dan secara umum tersebar pada kawasan IMTA dengan jarak 760 m dari KJA ikan. Karena berhubungan dengan kesuburan perairan maka kawasan ini dalam implementasinya dapat digunakan sebagai kawasan budidaya rumput laut atau kekerangan.
\end{abstract}

KATA KUNCl: fitoplankton, kelimpahan, indeks ekologi, analisa klaster, nutrien, Teluk Ekas

ABSTRACT: Spatial and temporal analysis of phytoplankton community around integrated marine aquaculture in Ekas Bay, West Nusa Tenggara. By: I Nyoman Radiarta, Erlania, and Ketut Sugama

Phytoplankton is the lowest trophic level that can be used as an indication of waters fertility. The objective of this study was to analyze spatial and temporal phytoplankton communities around integrated multi-trophic aquaculture (IMTA) in Ekas Bay, West Nusa Tenggara. Field sampling was conducted during six months observation program from June to November 2014. A total of nine stations were designed circular with distance of about $60 \mathrm{~m}$ and $150 \mathrm{~m}$ from the center point of IM TA (marine fish cages). All data were analyzed by descriptive, ecological indexes, and multivariate statistics. The results of species identification and abundance of phytoplankton showed that species of Nitzschia sp., Girosygma sp., and Coscinodiscus sp.; from class Bacillariophyceae were the dominant species found in the study area. Analysis of ecological index suggests that phytoplankton in study area has a low diversity index, low-medium dominance index, and high similarity index. Spatial and temporal abundance of phytoplankton indicated that thehigh abundance was found in August-October, and generally distributed with a distance $760 \mathrm{~m}$ from marine fish cages. Because associated with water fertility, this area could be used as seaweed or oysters aquaculture.

\section{KEYWORDS: phytoplankton, abundance, ecology indexes, cluster analysis, nutrient, Ekas Bay}

\section{PENDAHULUAN}

Fitoplankton merupakan organisme penting dari ekosistem perairan yang menduduki tingkat tropik terbawah. Kemampuannya melakukan proses fotosintesis, menjadikan organisme ini merupakan sumber

\# Korespondensi: Pusat Penelitian dan Pengembangan Perikanan Budidaya. Jl. Ragunan No. 20, Pasar Minggu, Jakarta Selatan 12540, Indonesia. Tel.: + (021) 7805051 E-mail: radiarta@yahoo.com energi yang diperlukan oleh semua kehidupan di ekosistem perairan baik secara langsung maupun tidak langsung, melalui pola rantai makanan (food chain). Kelompok fitoplankton yang umumnya dijumpai di perairan tropis adalah diatom (Bacillariophyceae) dan dinoflagelat (Dyno phyceae) (Nontji, 2008). Kelimpahan dan komposisi fitoplankton dalam perairan dapat dijadikan sebagai indikasi terhadap tingkat kesuburan dan perubahan kondisi perairan (Karydis \& Tsirtsis, 1996; Thoha \& Amri, 2011; Radiarta, 2013). Peran plank- 
ton juga sangat penting dalam aspek lingkungan global sehubungan dengan pemanasan global (Harley et al., 2006). Penelitian menunjukkan bahwa kemampuan fitoplankton untuk menyerap $\mathrm{CO}_{2}$ dari atmosfer, tidak kalah besarnya dengan kemampuan seluruh tumbuhan yang ada di daratan (Nontji, 2008). Oleh karena itu, kemampuan fitoplankton dalam menyerap $\mathrm{CO}_{2}$ membuat organisme ini dapat berfungsi pula sebagai pengendali iklim global (Adnan et al., 2010).

Teluk Ekas yang membujur dari Barat ke Timur di antara $116^{\circ} 23^{\prime}-116^{\circ} 29^{\prime}$ Bujur Timur dan $8^{\circ} 49^{\prime}-8^{\circ} 55^{\prime}$ Lintang Selatan, merupakan kawasan teluk terlindung yang masuk dalam dua kabupaten yaitu Kabupaten Lombok Tengah (Desa Awang) dan Kabupaten Lombok Timur (Desa Pamongkong, Desa Sukaraja, dan Desa Batunampar). Panjang garis pantai teluk sekitar $44 \mathrm{~km}$ dengan luasan mencapai 5.313 ha, dan merupakan kawasan teluk yang sangat berpotensi untuk pengembangan budidaya laut (Radiarta et al., 2003). Hal ini didukung karena Teluk Ekas memiliki karakteristik pantai yang relatif tenang, terlindung, dan banyaknya goba (lagoon). Kondisi oseanografi dan iklim di kawasan ini umumnya sangat mendukung untuk aktivitas budidaya laut (Manoppo et al., 2014). Aktivitas budidaya laut yang banyak berkembang di kawasan teluk ini adalah budidaya rumput laut dan ikan laut.

Budidaya laut terintegrasi yang berbasis integrated multi-trophic aquaculture (IMTA) dilakukan dengan tujuan untuk memanfaatkan semua ketersediaan energi yang ada di perairan oleh berbagai jenis komoditas yang dibudidayakan. Nutrien yang berasal dari sisa pakan, hasil metabolisme, dan ekskresi ikan akan ter- sebar di sekitar KJA ikan tersebut. Sebaran nutrien tersebut dapat dimanfaatkan oleh komoditas budidaya lainnya, seperti rumput laut, yang dapat mengekstrak dissolved inorganic nutrients dan kekerangan yang dapat memanfaatkan particulate organic matter, serta teripang, sehingga terjadi keseimbangan antara proses biologi dan kimia pada sistem yang berkembang (Neori et al., 2000; Barrington et al., 2009). Salah satu indikasi yang dapat digunakan untuk menunjukkan tingkat kesuburan perairan di sekitar unit budidaya terintegrasi adalah komposisi dan kelimpahan fitoplankton. Beberapa penelitian telah membuktikan adanya hubungan yang erat antara ketersediaan nutrien dengan kelimpahan fitoplankton (Gao \& Song, 2005; Garno, 2008; Radiarta, 2013). Penelitian ini bertujuan untuk melakukan analisis spasial dan temporal komunitas fitoplankton sekitar budidaya terintegrasi di Teluk Ekas, Nusa Tenggara Barat. Analisis yang digunakan dalam penelitian ini meliputi analisis deskriptif, spasial, dan statistik multivariat. Analisis spasial dilakukan dengan menggunakan sistem informasi geografis, sedangkan analisis statistik multivariat berdasarkan analisis klaster.

\section{BAHAN DAN METODE}

\section{Lokasi Penelitian dan Pengumpulan Data}

Penelitian dilaksanakan di Teluk Ekas Kabupaten Lombok Timur, Nusa Tenggara Barat. Kawasan penelitian terbentang pada posisi $8^{\circ} 52^{\prime} 20^{\prime \prime}-8^{\circ} 52^{\prime} 30^{\prime \prime}$ Lintang Selatan dan $116^{\circ} 26^{\prime} 55^{\prime \prime}-116^{\circ} 27^{\prime} 10^{\prime \prime}$ Bujur Timur (Gambar 1). Teluk Ekas sangat dipengaruhi oleh pola pasang surut harian dengan pola campuran yang cen-

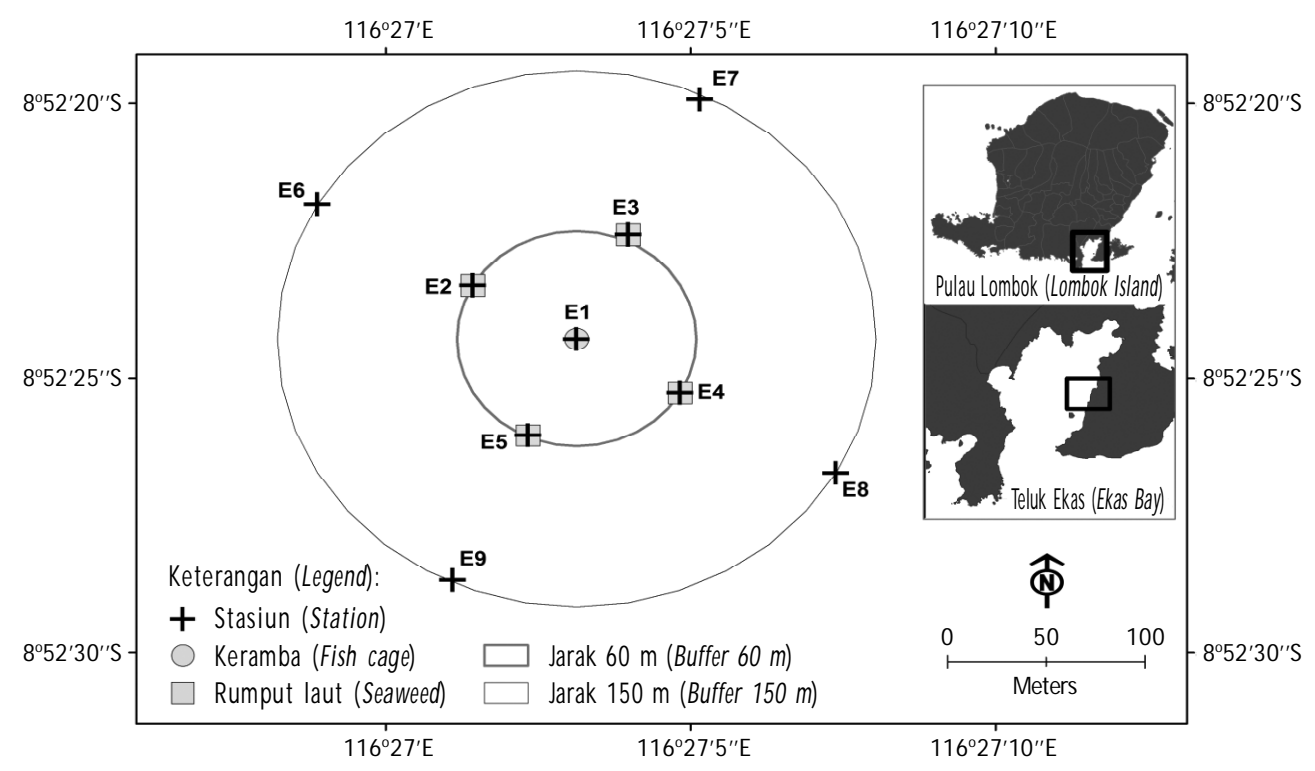

Gambar 1. Lokasi penelitian di Teluk Ekas Kabupaten Lombok Timur, Nusa Tenggara Barat (E1-E9 merupakan stasiun plankton)

Figure 1. The study area in Ekas Bay East Lombok Regency, West Nusa Tenggara (E1-E9 indicatethe plankton sampling stations) 
derung ke harian ganda (Nontji, 1993). Kondisi pasang surut ini sangat memengaruhi luasan area yang dapat digunakan untuk budidaya laut. Beberapa aktivitas budidaya yang telah berkembang di wilayah tersebut meliputi: budidaya rumput laut, budidaya ikan kerapu, dan budidaya lobster. Selain aktivitas budidaya laut, aktivitas penangkapan juga berkembang pesat terutama penangkapan benih lobster alam. Dengan potensi yang dimiliki ini, kawasan Teluk Ekas telah dijadikan lokasi percontohan pengembangan program blue economy Kementerian Kelautan dan Perikanan (KKP, 2014).

Pengumpulan data dilakukan pada bulan JuniNovember 2014 di sekitar sistem budidaya terintegrasi (IMTA). Sistem IMTA yang terdapat di lapangan merupakan kombinasi dari ikan bawal bintang (Trachinotus Blochii, Lacepede), rumput laut (Kappaphycus alvarezii), dan abalon (Haliotis asinina). Keramba jaring apung (KJA) merupakan titik pusat IMTA dengan posisi: $116.45087^{\circ} \mathrm{BT} ;-8.87341^{\circ} \mathrm{LS}$, sedangkan unit rumput laut dipasang diagonal pada empat titik: E2, E3, E4, dan E5 (Gambar 1). Pengambilan contoh air untuk parameter biologi (plankton) menggunakan ember dengan kapasitas 10 liter dengan 10 kali penyaringan, menggunakan plankton net no. 25 dengan ukuran mata jaring $64 \mu \mathrm{m}$ (APHA, 1989; Nontji, 2008). Hasil penyaringan dimasukkan ke dalam botol volume 100 $\mathrm{mL}$ dari 100 liter sampel air laut yang disaring. Sampel diawetkan dengan lugol $1 \mathrm{~mL} / 100 \mathrm{~mL}$. Metode pengambilan, preservasi, dan analisis contoh air mengacu pada metode standar APHA (2005). Contoh air kemudian dianalisis di Laboratorium Air Biotrop, Bogor untuk mengetahui jenis, komposisi dan kelimpahan fitoplankton.

\section{Analisis Kelimpahan dan Indeks Ekologi Fito- plankton}

Perhitungan kelimpahan fitoplankton dilakukan dengan Sedwick Rafter Counter (SRC) yang dilihat menggunakan alat bantu mikroskop (APHA, 1989). Kelimpahan fitoplankton dihitung dalam individu/L menggunakan rumus:

$$
N=\frac{O_{i}}{O_{p}} \times \frac{V_{r}}{V_{o}} \times \frac{1}{V_{s}} \times \frac{n}{p}
$$

di mana:

$\mathrm{N}=$ Jumlah individu per liter

$\mathrm{O}_{\mathrm{i}}=$ Luas gelas penutup preparat $\left(\mathrm{mm}^{2}\right)$

$\mathrm{O}_{\mathrm{p}}=$ Luas satu lapangan pandang $\left(\mathrm{mm}^{2}\right)$

$\mathrm{V}_{\mathrm{r}}=$ Volume air tersaring $(\mathrm{mL})$

$\mathrm{V}_{0}=$ Volume air yang diamati $(\mathrm{mL})$

$\mathrm{V}_{\mathrm{s}}=$ Volume air yang disaring (L)

$\mathrm{n}=$ Jumlah plankton pada seluruh lapangan pandang

$\mathrm{p}=$ Jumlah lapangan pandang yang teramati
Selain kelimpahan, perhitungan beberapa indeks ekologi juga dilakukan. Perhitungan indeks ekologi tersebut meliputi indeks dominansi (Simpson's Index D), indeks keanekaragaman (Shannon-Wiener Index $\mathrm{H}^{\prime}$ ), dan indeks keseragaman (Evenness Index - E). Perhitungan indeks tersebut mengacu pada Odum (1971), dengan persamaan sebagai berikut:

$$
\begin{gathered}
D=\sum_{i}^{s}\left(P_{i}^{2}\right) \\
H^{\prime}=-\sum_{i}^{s} P_{i} \ln \left(P_{i}\right) \\
E=\frac{H^{\prime}}{\ln S}
\end{gathered}
$$

di mana:

$P=N_{i} / N$

$\mathrm{N}_{\mathrm{i}}=$ Jumlah individu genus ke-i

$\mathrm{N}=$ Jumlah total individu seluruh genera

$\mathrm{S}=$ Jumlah spesies

Distribusi spasial dan temporal kelimpahan fitoplankton dianalisis dengan teknik inverse distance weighted (IDW) (Johnson \& McChow, 2001), yang terdapat dalam perangkat lunak ArcGIS v.10 (The Environmental System Research Institute (ESRI), USA).

\section{Analisis Klaster}

Analisis klaster yang digunakan dalam penelitian ini bertujuan untuk mengklasifikasikan lokasi pengamatan berdasarkan karakteristik yang mereka miliki. Analisis kluster merupakan salah satu aplikasi dari statistik multivariat. Menurut Varol \& Sen (2009) dan Kamble \& Vijay (2011), melalui analisis kluster maka objek yang serupa akan dikelompokkan dalam klaster yang sama, sesuai dengan kriteria yang digunakan. Hasil yang diperoleh dari analisis ini mengelompokkan stasiun dalam satu kelompok dengan tingkat kesamaan yang tinggi dan membagi menjadi kelompok yang berbeda dengan tingkat ketidaksamaan yang tinggi. Hasil analisis ini dapat ditampilkan dalam bentuk dendogram (diagram pohon). Pada penelitian ini analisis klaster menggunakan hierarchical agglomerative clustering dengan metode Ward (Ward's method) dan squared Euclidean distances. Perangkat lunak yang digunakan untuk analisis klaster dan statistik korelasi Pearson adalah SPSS v. 10.

\section{HASIL DAN BAHASAN}

\section{Struktur Komunitas Fitoplankton}

Berdasarkan hasil analisis fitoplankton selama enam bulan pengamatan (Juni-November 2014), sebanyak 13 jenis fitoplankton ditemukan di lokasi penelitian yang terkelompok menjadi tiga kelas yaitu: 
Bacillariophyceae, Chlorophyceae, dan Dinophyceae (Tabel 1). Tiga jenis fitoplankton dengan kelimpahan terbesar yang ditemukan adalah Nitzschia sp., Girosygma sp., dan Coscinodiscus sp., dengan kelimpahan masingmasing 26.928 ind./L, 24.816 ind./L, dan 23.232 ind./ L; semua jenis ini berasal dari kelas Bacillariophyceae (Diatom). Diatom merupakan kelas fitoplankton yang paling sering ditemukan di perairan Indonesia (Nontji, 2008). Dominansi kelas diatom pada suatu perairan karena mempunyai kemampuan beradaptasi dengan lingkungan, bersifat kosmopolit, dan tahan terhadap kondisi ekstrim, serta mempunyai daya reproduksi yang tinggi (Odum, 1971).

Dari seluruh jenis yang ditemukan di lokasi penelitian, terdapat beberapa jenis yang dalam kelimpahan tinggi dapat membahayakan organisme lainnya yaitu: Nitzschia sp., Ceratium sp., dan Dinophysis sp. (Wiadnyana, 1996; Garno, 2008). Berdasarkan Wiadnyana (1996), Nitzschia sp. dan Dinophysis sp. masuk dalam kategori alga beracun yang dapat menyebabkan berbagai macam penyakit perut dan sistem syaraf. Kelimpahan fitoplankton pada suatu kawasan sangat dipengaruhi oleh unsur hara, kondisi arus, cahaya, dan angin. Beberapa penelitian telah membuktikan bahwa terhadap hubungan yang erat antara ketersediaan unsur hara dengan kelimpahan fitoplankton (Soedibjo, 2006; Radiarta, 2013).

Tabel 1. Jenis dan kelimpahan fitoplankton yang ditemukan sekitar unit IMTA di Teluk Ekas, Nusa Tenggara Barat

Table 1. Phytoplankton species and abundance around IMTA system in Ekas Bay, West Nusa Tenggara

\begin{tabular}{lc}
\hline Jenis (Species) & $\begin{array}{c}\text { Kelimpahan (Abundance) } \\
\text { (ind./L) }\end{array}$ \\
\hline Bacillariophyceae & \\
Asterionella sp. & 8,096 \\
Bacteriastrum sp. & 15,312 \\
Biddul phia sp. & 6,512 \\
Coscinodiscus sp. & 23,232 \\
Girosygma sp. & 24,816 \\
Hemiaulus sp. & 7,744 \\
Lauderia sp. & 1,232 \\
Nitzschia sp. & 26,928 \\
Rhizosolenia sp. & 7,920 \\
Surirella sp. & 176 \\
\hline Chlorophyceae & \\
Triceratium sp. & 528 \\
Ceratium sp. & 3,344 \\
\hline Dinophyceae & \\
Dinophysis sp. & 1,056 \\
\hline
\end{tabular}

Kelimpahan dan jenis fitoplankton hasil pengamatan selama enam bulan menunjukkan hasil yang berfluktuasi baik secara waktu maupun tempat (Gambar 2). Kelimpahan tertinggi ditemukan pada bulan September di stasiun E3 (6.864 ind./L), kemudian bulan Oktober di stasiun E4 (6.512 ind./L). Berdasarkan lokasi pengamatan, stasiun yang berjarak $60 \mathrm{~m}$ (E2, E3, E4, dan E5) dari titik pusat IMTA (KJA ikan) umumnya memiliki kelimpahan dan jumlah jenis yang lebih tinggi dibandingkan dengan stasiun yang berjarak 150 m (E6, E7, E8, dan E9). Sedangkan berdasarkan waktu pengamatan, bulan Agustus-Oktober merupakan waktu pengamatan dengan kelimpahan dan jumlah jenis tertinggi (Gambar 2). Kondisi ini sangat sesuai dengan hasil analisis kondisi nutrien sekitar unit IMTA yang dilakukan oleh Radiarta \& Erlania (2015), yang menunjukkan bahwa kelimpahan nutrien (amonia, nitrat, dan ortho-fosfat) terbesar ditemukan antara bulan Agustus-Oktober 2014, dengan konsentrasi terbesar pada jarak $60 \mathrm{~m}$ dari titik pusat IMTA. Hal ini menunjukkan bahwa konsentrasi nutrien merupakan faktor penting yang sangat memengaruhi kelimpahan dan jumlah jenis fitoplankton di kawasan penelitian. Selain konsentrasi nutrien, faktor lainnya seperti kondisi arus dan kecepatan angin juga dapat memengaruhi kelimpahan fitoplankton (Garno, 2008). Manoppo et al. (2014) mengungkapkan bahwa kecepatan arus di sekitar Pulau Lombok berkisar antara 24-55 cm/dt; dengan kecepatan maksimum terjadi pada bulan Juli 2014 yang mencapai $55 \mathrm{~cm} / \mathrm{dt}$. Sedangkan kecepatan angin maksimum terpantau pada bulan Juli-Agustus 2014 yang berkisar antara 3,58-7,75 $\mathrm{m} / \mathrm{dt}$ (Manoppo et al., 2014). Hasil kajian Radiarta et al. (2003) menunjukkan bahwa kondisi arus di Teluk Ekas umumnya dipengaruhi oleh pergerakan pasang surut dengan kecepatan antara 1-18 m/menit.

Untuk melihat tingkat stabilitas lingkungan perairan, beberapa indeks ekologi fitoplankton telah dihitung meliputi: indeks keanekaragaman $\left(\mathrm{H}^{\prime}\right)$, indeks dominansi (D), dan indeks keseragaman (E) (Gambar 3). Indeks ekologi ini sering kali juga digunakan sebagai acuan untuk melihat tingkat eutrofikasi suatu perairan (Karydis \& Tsirtsis, 1996). Indeks keanekaragaman di lokasi penelitian cukup bervariasi baik waktu dan tempat (Gambar 3). Indeks keanekaragaman terbesar ditemukan pada bulan Agustus-September 2014 dengan kisaran antara 1,45-1,89. Menurut Margalef (1978) dalam Soedibjo (2006), bahwa indeks keanekaragaman fitoplankton umumnya berkisar antara 1-2,5 untuk wilayah pantai, khususnya daerah estuari, daerah tercemar atau kawasan upwelling. Kisaran indeks yang diperoleh ini masih masuk dalam kriteria keanekaragaman yang rendah (Odum, 1971). Indeks keanekaragaman Shannon-Wiener merupakan indeks yang paling sering digunakan untuk melihat 


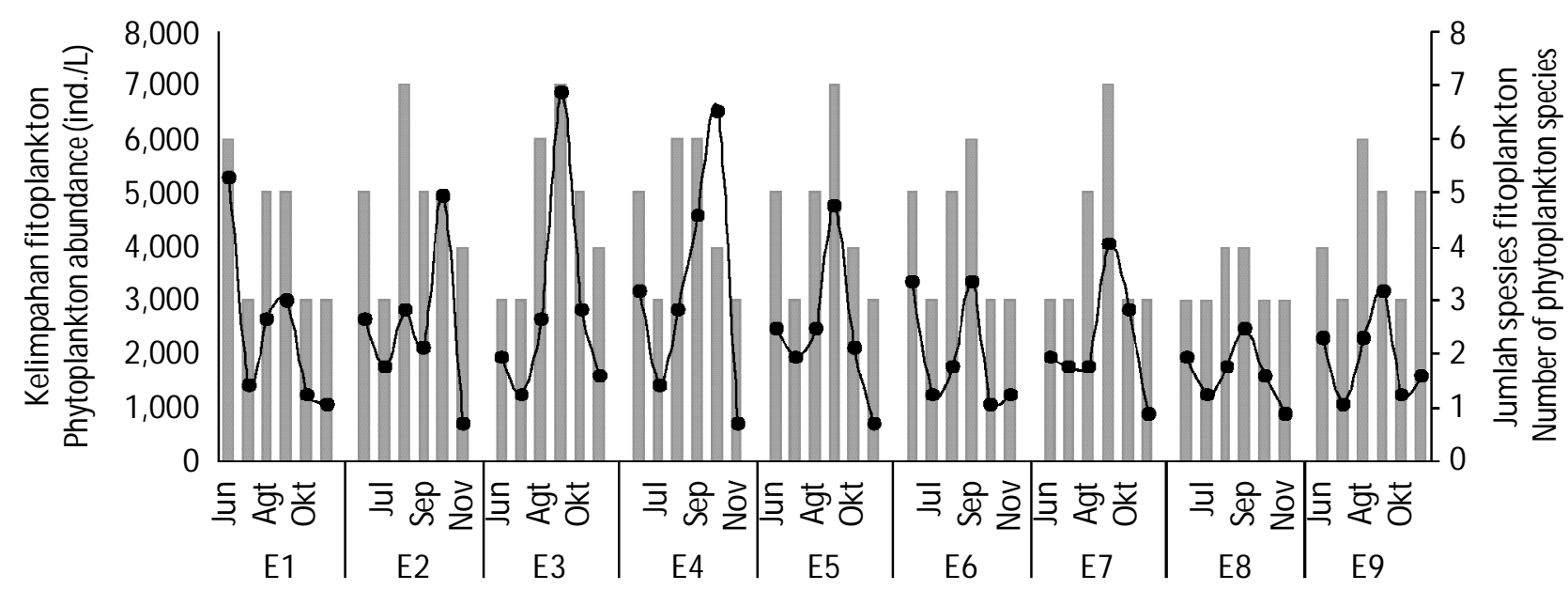

Stasiun pengamatan (bulan)

Observation stations (months)

Gambar 2. Kelimpahan dan jumlah spesies fitoplankton sekitar sistem IMTA di Teluk Ekas, Nusa Tenggara Barat

Figure 2. Number of species and abundance of phytoplankton around IMTA system in Ekas Bay, West Nusa Tenggara

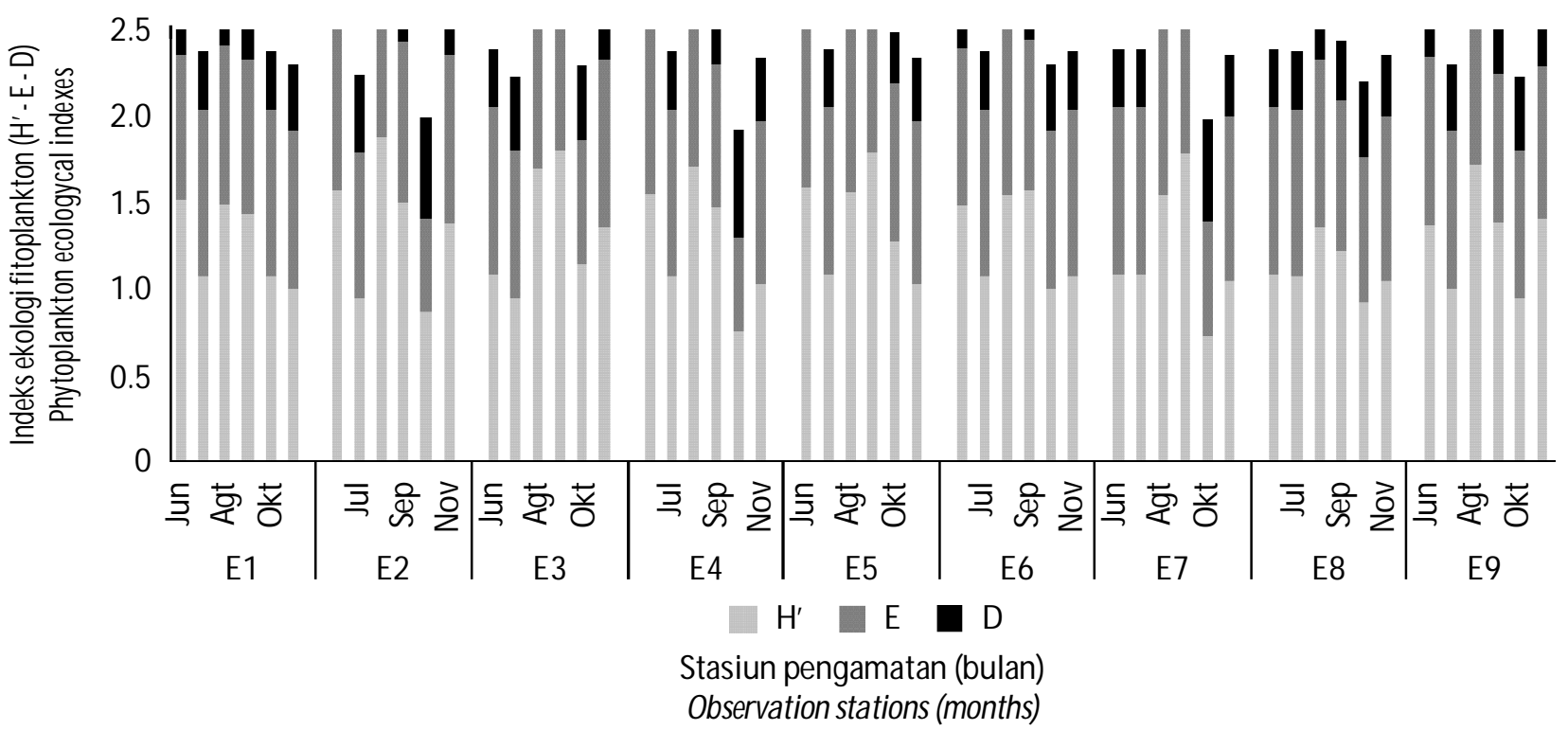

Gambar 3. Variasi spasial dan temporal indeks ekologi $\left(H^{\prime}, E\right.$, dan D) fitoplankton sekitar sistem IMTA di Teluk Ekas, Nusa Tenggara Barat

Figure 3. Spatial and temporal variation ecologycal indexes of phytoplankton around IMTA system in Ekas Bay, West Nusa Tenggara

tingkat keanekaragaman organisme dan sering digunakan sebagai indikator bagi kualitas perairan (Gao \& Song, 2005). Indeks dominansi fitoplankton di lokasi penelitian berkisar antara 0,16-0,63. Nilai indeks dominansi ini tergolong kategori rendah-sedang. Nilai indeks dominansi yang mendekati satu menunjukkan adanya jenis yang dominan (Odum, 1971). Menurut Karydis \& Tsirtsis (1996), indeks keseragaman merupakan indeks yang dapat dengan jelas membedakan status tingkat tropik dari suatu perairan. Kisaran indeks keseragaman yang diperoleh dari penelitian ini berkisar antara 0,55-1,00. Nilai indeks ini menunjukkan tingkat keseragaman yang tinggi.

Korelasi struktur komunitas fitoplankton yang meliputi jumlah jenis, kelimpahan, indeks keanekaragaman, indeks keseragaman, dan indeks dominansi ditampilkan pada Tabel 2. Terdapat korelasi yang sangat signifikan $(99 \%$ antara struktur komunitas fitoplankton di lokasi penelitian. Hubungan positif yang kuat ditemukan antara jumlah jenis dan kelimpahan dengan indeks keanekaragaman dan indeks keseragaman. Sebaliknya hubungan negatif ditemukan antara 
Tabel 2. Korelasi Pearson struktur komunitas fitoplankton sekitar unit IMTA di Teluk Ekas, Nusa Tenggara Barat

Table 2. Pearson correlation of community structure for phytoplankton around IMTA system in Ekas Bay, West Nusa Tenggara

\begin{tabular}{lccccc}
\hline & $\begin{array}{c}\text { Jumlah spesies } \\
\text { Number of species }\end{array}$ & $\begin{array}{c}\text { Kelimpahan (Abundance) } \\
\text { (ind./L) }\end{array}$ & H' & E & D \\
\hline Jumlah spesies (Number of species) & 1 & $0.694^{* *}$ & $0.886^{* *}$ & -0.077 & $-0.637^{* *}$ \\
Kelimpahan (Abundance) (ind./L) & $0.694^{* *}$ & 1 & $0.390^{* *}$ & $-0.518^{* *}$ & -0.071 \\
$H^{\prime}$ & $0.886^{* *}$ & $0.390^{* *}$ & 1 & $0.377^{* *}$ & $-0.918^{* *}$ \\
E & -0.077 & $-0.518^{* *}$ & $0.377^{* *}$ & 1 & $-0.704^{* *}$ \\
D & $-0.637^{* *}$ & -0.071 & $-0.918^{* *}$ & $-0.704^{* *}$ & 1 \\
\hline
\end{tabular}

Keterangan (Note):

$H^{\prime}=$ Shannon-Wiener Index; $E$ = Evenness Index; D = Simpson's Index; ${ }^{*}$ Signifikan pada level $99 \%(0,01)($ Correlation is significant at the level $99 \%(0.01))$

indeks dominansi dengan jumlah jenis, kelimpahan, indeks keanekaragaman, dan indeks keseragaman. Positif korelasi antara indeks keanekaragaman dengan indeks keseragaman juga ditemukan oleh Gao \& Song (2005) saat melihat distribusi fitoplankton di kawasan estuari Changjiang, Cina. Radiarta (2013) juga menemukan hubungan yang erat baik positif maupun negatif untuk struktur komunitas fitoplankton di perairan Selat Alas, Sumbawa. Adanya proses ekologi utama seperti kompetisi, predasi, dan suksesi dapat merubah kondisi keanekaragaman fitoplankton perubahan kemerataan tanpa perubahan kekayaan spesies (Gao \& Song, 2005).

\section{Distribusi Spasial Fitoplankton}

Analisis spasial dan temporal kelimpahan fitoplankton ditampilkan pada Gambar 4. Terdapat variasi kelimpahan selama enam bulan pengamatan (JuniNovember 2014), dengan kelimpahan tertinggi ditemukan pada bulan September-Oktober. Secara spasial, kelimpahan yang tinggi umumnya terletak pada daerah dengan jarak $60 \mathrm{~m}$ dari titik utama IMTA (KJA ikan). Selain jarak, kelimpahan pada titik pengamatan juga bervariasi, yaitu arah Utara, Selatan, Timur, dan Barat. Pada bulan Juni saat awal penelitian dilakukan, kelimpahan fitoplankton yang tinggi terkonsentrasi pada titik utama IMTA yaitu KJA ikan laut. Kemudian bulan-bulan selanjutnya sebaran kelimpahan fitoplankton memiliki pola yang berbeda. Bulan Juli, September, dan Oktober sebarannya mengikuti pola UtaraSelatan, sedangkan bulan Agustus dan Oktober mengikuti pola Timur-Barat. Pola sebaran kelimpahan fitoplankton ini diduga mendapat pengaruh dari kecepatan dan arah arus, serta angin yang terjadi di

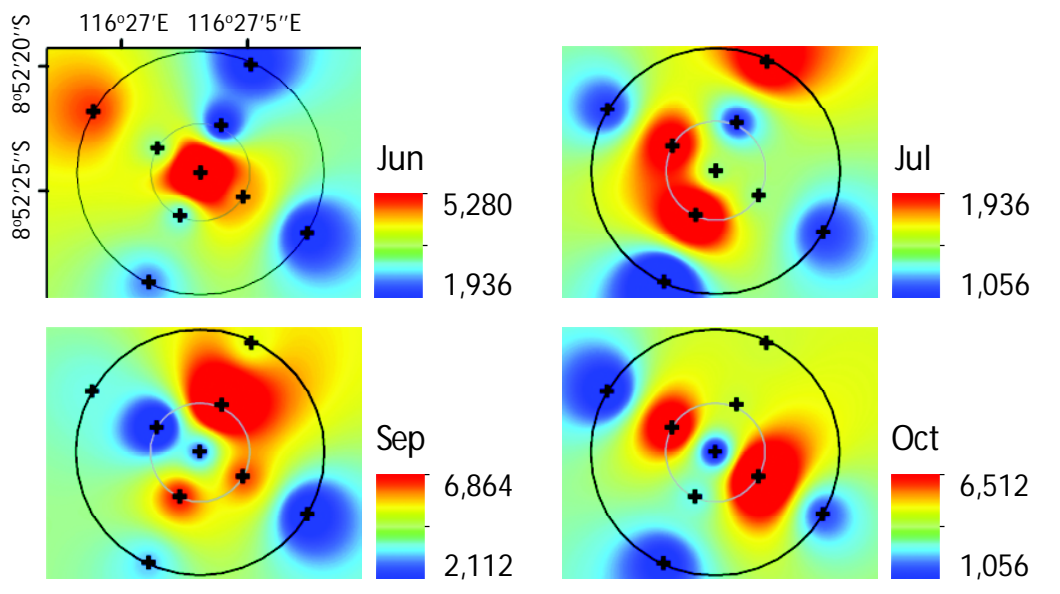

$+=$ Stasiun pengamatan (Sampling stations)
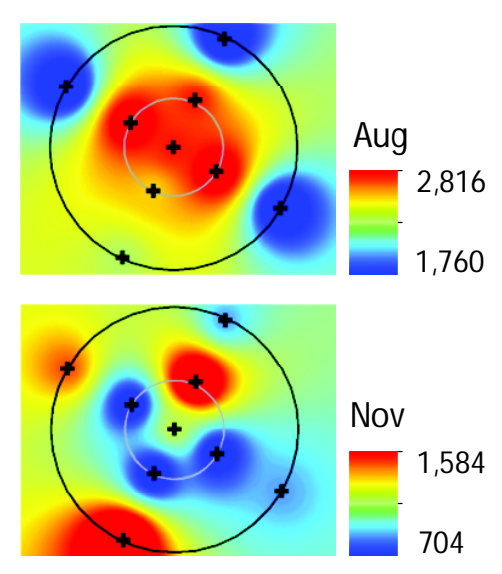

霖 $\quad 00125 \quad 250$ Meters

Gambar 4. Variasi spasial dan temporal kelimpahan fitoplankton (ind./L) sekitar sistem IMTA di Teluk Ekas, Nusa Tenggara Barat

Figure 4. Spatial and temporal variations of phytoplankton abundance (ind./L) around IMTA system in Ekas Bay, West Nusa Tenggara 


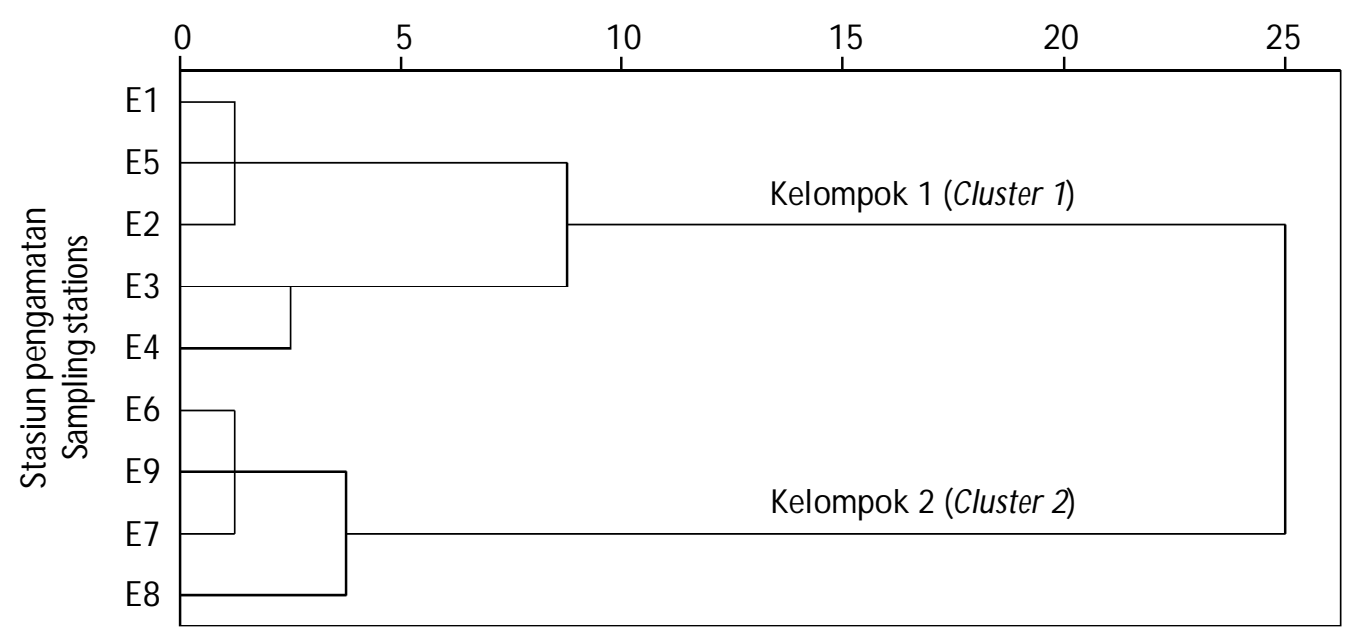

Gambar 5. Dendrogram menunjukkan pengelompokan berdasarkan lokasi pengamatan fitoplankton di Teluk Ekas, Lombok Timur, Nusa Tenggara Barat

Figure 5. Dendrogram showing clustering of monitoring sites of phytoplankton in Ekas Bay, East Lombok, West Nusa Tenggara

lokasi penelitian. Pada bulan September, arus perairan bergerak dari Utara ke Selatan; sedangkan bulan Oktober arus bergerak dari Barat ke Timur. Hal ini juga didukung oleh hembusan angin yang searah dengan arah arus tersebut (Manoppo et al., 2014).

Selain faktor arus dan angin, kelimpahan fitoplankton yang tinggi ditemukan sekitar jarak $60 \mathrm{~m}$ dari titik pusat IMTA berhubungan dengan ketersediaan kandungan nutrien sekitar kawasan tersebut. Hasil analisis Radiarta \& Erlania (2015), menunjukkan bahwa kelimpahan nutrien (amonia, nitrat, dan orthofosfat) terbesar ditemukan pada jarak $60 \mathrm{~m}$ dari titik pusat IMTA. Telah banyak kajian yang memperlihatkan hubungan yang erat antara ketersediaan unsur hara dengan kelimpahan fitoplankton (Chrismadha \& Ali, 2007; Mujiyanto et al., 2011; Hossain et al., 2012; Radiarta, 2013).

\section{Analisis Klaster}

Analisis klaster pada penelitian ini dilakukan dengan tujuan untuk melihat bagaimana fitoplankton dikelompokkan berdasarkan kelimpahan dan jumlah jenis di masing-masing stasiun selama enam bulan pengamatan (Juni-November 2014). Berdasarkan analisis klaster, stasiun pengamatan dibagi menjadi dua kelompok yang memiliki karakteristik yang cukup berbeda antara kedua kelompok tersebut (Gambar 5). Kelompok pertama terdiri atas lima stasiun pengamatan yaitu: E1, E2, E3, E4, dan E5. Stasiun pengamatan yang masuk dalam kelompok ini merupakan stasiun titik pusat IMTA dan stasiun yang berjarak $60 \mathrm{~m}$. Sedangkan kelompok kedua yang terdiri atas stasiun E6, E7, E8, dan E9 merupakan stasiun yang berjarak $150 \mathrm{~m}$ dari titik pusat IMTA. Sangat jelas terlihat bahwa pembagian kelompok ini merupakan penajaman analisis yang dilakukan secara deskriptif (Gambar 2) dan spasial (Gambar 4). Dengan pendekatan analisis klaster ini memperlihatkan cukup baik dalam menggambarkan pengelompokkan stasiun pengamatan di lokasi penelitian. Soedibjo (2006) juga telah menggunakan analisis klaster untuk melihat pola pengelompokkan fitoplankton di perairan Teluk Jakarta.

\section{KESIMPULAN}

Tingkat kesuburan perairan dapat diindikasikan dengan kelimpahan fitoplankton. Hal ini disebabkan karena fitoplankton menduduki trofik level paling bawah yang memanfaatkan langsung unsur hara dalam perairan. Hasil penelitian ini menunjukkan bahwa fitoplankton yang ditemukan selama enam bulan pengamatan didominasi jenis Nitzschia sp., Girosygma sp., dan Coscinodiscus sp.; dari kelas Bacillario phyceae. Berdasarkan analisis spasial dan temporal menunjukkan bahwa kelimpahan fitoplankton terbesar ditemukan pada bulan Agustus-Oktober, dengan jarak sekitar $60 \mathrm{~m}$ dari titik pusat unit IMTA. Karakteristik ini lebih dipertajam lagi melalui analisis klaster yang membagi seluruh stasiun pengamatan menjadi dua kelompok yaitu kelompok pertama yang merupakan stasiun pada jarak sampai dengan $60 \mathrm{~m}$ dan kelompok kedua dengan lokasi stasiun lebih besar dari 60 $\mathrm{m}$. Karakteristik fitoplankton yang ditemukan di sekitar kawasan budidaya terintegrasi ini menunjukkan secara nyata bahwa kawasan sekitar titik pusat IMTA (dengan jarak $760 \mathrm{~m}$ ) merupakan kawasan yang subur dengan kandungan nutrien yang berlimpah. Kawasan ini dalam implementasinya dapat digunakan sebagai kawasan budidaya rumput laut atau kekerangan. 


\section{UCAPAN TERIMA KASIH}

Penulis mengucapkan terima kasih kepada Balai Budidaya Laut (BBL) Lombok di Sekotong atas bantuannya selama kegiatan lapangan. Kami juga mengucapkan terima kasih kepada Gede Sumarthana (penyuluh BBL Lombok) dan pembudidaya ikan di Ekas (Bapak Alimin dan Idin) yang telah membantu kelancaran pengumpulan data selama penelitian dilaksanakan. Penelitian ini dibiayai oleh DIPA Pusat Penelitian dan Pengembangan Perikanan Budidaya T.A. 2014.

\section{DAFTAR ACUAN}

Adnan, Q., Thoha, H., \& Fitriya, N. (2010). Dampak pemanasan global terhadap kondisi plankton di perairan Teluk Jakarta. Laporan Akhir Program Intensif Penelitian dan Perekayasa LIPI, $39 \mathrm{hlm}$.

American Public Health Association (APHA). (1989). Standard methods for the examination of water and waste water including bottom sediment and sludges. $17^{\text {th }} \mathrm{Ed}$. Amer. Publ. Health Association Inc. New York, 1527 pp.

American Public Health Association (APHA). (2005). Standard methods for the examination of water and wastewater. $21^{\text {st }}$ Edition. American Water Works Association (AWWA)/American Public Works Association/Water Environment Federation. Washington. USA, 1368 pp.

Barrington, K., Chopin, T., \& Robinson, S. (2009). Integrated multi-trophic aquaculture (IMTA) in marine temperate waters. In Soto, D. (Ed.). Integrated mariculture: a global review. FAO Fisheries and Aquaculture Technical Paper. No. 529. Rome, p. 7-46.

Chrismadha, T., \& Ali, F. (2007). Dinamika komunitas fitoplankton pada kolam sistem aliran tertutup berarus deras. Oseanologi dan Limnologi di Indonesia, 3, 325-338.

Gao, X., \& Song, J. (2005). Phytoplankton distribution and their relationship with the environment in the Cahngjiang Estuary, China. Marine Pollution Bulletin, 50, 327-335.

Garno, Y.S. (2008). Kualitas air dan dinamika fitoplankton di perairan Pulau Harapan. Jurnal Hidrosfir Indonesia, 3, 87-94.

Harley, C.D.G., Hughes, R.A., Hultgren, K.M., Miner, B.G., Sorte, C.J.B., Thornber, C.S., Rodriguez, L.F., Tomanek, L., \& Williams, S.L. (2006). The impacts of climate change in coastal marine systems. Ecology Letters, 9, 228-241.

Hossain, Md.Y., Jewel, Md.A.S., Fulanda, B., Ahamed, F., Rahman, S., Jasmine, S., \& Ohtomi, J. (2012). Dynamic of cyanobacteria planktohrix species (Oscillatoriales: Phormidiaceae) in earthen fish ponds, Northwestern Bangladesh. Sains Malaysi- ana, 41(3), 277-284.

Johnson, K., \& McChow, J. (2001). Using ArcGIS spatial analysis. Environmental Systems Research Institute (ESRI), Inc. USA, 236 pp.

Kamble, S.R., \& Vijay, R. (2011). Assessment of water quality using cluster analysis in coastal region of Mumbai, India. Environ. M onit. Assess., 178, 321332.

Karydis, M. \& Tsirtsis, G. (1996). Ecological indeces: a biometric approach for assessing eutropication levels in the marine environment. The Science of the Environment, 186, 209-219.

Kementerian Kelautan dan Perikanan [KKP]. (2014). Blue economy: pembangunan kelautan dan perikanan berkelanjutan. Kementerian Kelautan dan Perikanan. Jakarta, $240 \mathrm{hlm}$.

Manoppo, A.K.S., Emiyati, Budhiman, S., \& Hasyim, B. (2014). Ekstraksi informasi keterlindungan perairan dari data penginderaan jauh untuk kesesuaian budidaya rumput laut di Pulau Lombok. Prosiding Seminar Nasional Penginderaan Jauh. Jakarta, hlm. 598-609.

Mujiyanto, Tjahjo, D.W.H., \& Sugianti, Y. (2011). Hubungan antara kelimpahan fitoplankton dengan konsentrasi $\mathrm{N}$ : P pada daerah keramba jaring apung (KJA) di Waduk Ir. H. Djuanda. Limnotek, 18, 15-25.

Neori, A., Spigel, M., \& Ben-Ezra, D. (2000). A sustainable integrated system for culture of fish, seaweed and abalone. Aquaculture, 186, 297-291.

Nontji, A. (1993). Laut Nusantara. Penerbit Djambatan. Jakarta. ISBN 979428204 11, 362 hlm.

Nontji, A. (2008). Plankton laut. Pusat Penelitian Oseanografi. Lembaga IImu Pengetahuan Indonesia (LIPI). LIPI Press, $331 \mathrm{hlm}$.

Odum, E.P. (1971). Fundamentals of ecology. Third edition. Saunders, W.B. Company. Philadelphia, London, Toronto, $574 \mathrm{pp}$.

Radiarta, I N., Wardoyo, S.E., Priono, B., \& Praseno, O. (2003). Aplikasi sistem informasi geografis untuk penentuan lokasi pengembangan budidaya ikan laut di Teluk Ekas, Nusa Tenggara Barat. Jurnal Penelitian Perikanan Indonesia, Edisi Akuakultur, 9(1), 67-80.

Radiarta, I N. (2013). Hubungan antara distribusi fitoplankton dengan kualitas perairan di Selat Alas, Kabupaten Sumbawa, Nusa Tenggara Barat. Jurnal Bumi Lestari, 13(2), 234-243.

Radiarta, I N., \& Erlania. (2015). Indeks kualitas perairan dan sebaran nutrien sekitar budidaya laut terintegrasi di Teluk Ekas, Nusa Tenggara Barat: aspek penting budidaya rumput laut. Jurnal Riset Akuakultur, 10(1), 141-152.

Soedibjo, B.S. (2006). Struktur komunitas fitoplankton dan hubungannya dengan beberapa parame- 
ter lingkungan di perairan Teluk Jakarta. Oseanologi dan Limnologi di Indonesia, 40, 65-78.

Thoha, H., \& Amri, K. (2011). Komposisi dan kelimpahan fitoplankton di perairan Kalimantan Selatan. Oseanologi dan Limnologi di Indonesia, 37(2), 371382.
Varol, M., \& Sen, B. (2009). Assessment of surface water quality using multivariate statistical techniques: a case study of Behrimaz Stream, Turkey. Environ. Monit. Assess., 159, 543-553.

Wiadnyana, N.N. (1996). Mikroalga berbahaya di perairan Indonesia. Oseanologi dan Limnologi di Indonesia, 19, 15-28. 